\title{
The Effect of Spiritual Emotional Freedom Technique (SEFT) on the Self Concept of Breast Cancer Patients with Mastectomy
}

\author{
Esi Afriyanti, Bunga Permata Wenni \\ Faculty of Nursing University Andalas \\ Email:esiafriyanti@nrs.unand.ac.id
}

Submitted: 27-03-2018 Accepted: 29-12-2018 Published: 29-12-2018

\begin{abstract}
Mastectomy is a breast cancer surgical therapy that can lead to permanent changes in a woman's appearance. This change can cause negative changes in a woman's self-concept. If the disruption of self-concept continues, it will cause emotional weakness. Individuals will be depressed and feel anxious continuously, emotional frustration is getting worse, making individuals create self-destruction. For this reason, therapy is needed that can overcome this negative self-concept problem from Emotional Freedom Technique (SEFT) Spiritual Therapy. The aim of this study was to identify the effects of SEFT therapy on self-concept in women with breast cancer with a mastectomy. This study used a quasi-experimental design with one group pretest-posttest design approach with inclusion criteria willing to be a research subject, aware, no hearing loss or cognitive impairment of self-concept, never had SEFT therapy, interacted with family and community at least 1 week after mastectomy. This therapy was carried out for 3 days in 33 subjects. Data were analyzed by Chi square statistical test with $95 \%$ CI with a significance of $p<0.05$. The results of this study were before given SEFT treatment from 33 respondents, there were 4 respondents $(12.1 \%)$ who had a positive self-concept, and the majority of 29 respondents $(87.9 \%)$ had negative self-concept. After SEFT treatment there was an increase in self-concept of respondents with positive self-concept as many as 10 people (30.3\%) and still had negative self-concept as many as 23 people (69.7\%). The results of the analysis showed that there were differences in self-concept before and after SEFT with a value of $p=0.05$. Nurses are encouraged to exercise this ability and use this therapy as a therapy to prevent self-concept disorders in breast cancer patients with mastectomy.
\end{abstract}

Keywords : Breast cancer, patients, mastectomy. 
Esi Afriyanti : The Effect of Spiritual Emotional Freedom Technique (SEFT) on the Self Concept

\section{Introduction}

Cancer is a non-communicable disease that is still the biggest cause of death in humans around the world. WHO data shows that in 2012 , the death rate of the world's population due to cancer reached 8.2 million cases. It is even expected to increase to 22 million cases in the next 2 decades. In Indonesia alone, the prevalence of cancer is $0.14 \%$. Cancer is the number seven cause of death in Indonesia, however, based on age, cancer prevalence is in the age group 45-54 years where the age is still a productive age (Balitbang Basic Health Research Ministry of Health, 2013). Of the many types of cancer, cervical and breast cancer ranks highest in Indonesia with a case of $0.08 \%$ in cervical cancer, and breast cancer with a prevalence rate of $0.05 \%$ (Balitbang Basic Health Research Ministry of Health, 2013).

Breast cancer therapy modalities include surgery, chemotherapy, hormonal therapy, monoclonal antibodies (therapeutic genes) and immunotherapy (Gnant, 2015). In surgical procedures for breast cancer, usually is removal of the breast known as mastectomy. Mastectomy, as a surgical treatment for breast cancer, results in permanent changes in a woman's appearance. Breasts are considered part of women's identity in Indonesia and various other cultures (Koçan, 2016). Breasts represent femininity, sexuality, beauty, motherhood, and breastfeeding babies (Cebeci, 2011). The loss of one of these attributes can cause a negative change in one's self-concept (Arroyo, 2011).

Self-concept is an individual's way of seeing his personality as a whole, involving physical, emotional, intellectual, social, and spiritual, including the individual's perception of the nature and potential that they have, the interaction of individuals with others and their environment, values related to experience and objects, as well as their goals, hopes and desires (Sunaryo, 2004). Self-concept is of two types, namely positive self-concept and negative self-concept (Stuart \& Sundeen, 1991). Individuals who have a negative self-concept believe and perceive that they are weak, helpless, unable to do anything, incompetent, failed, unfortunate, unattractive, disliked and lose interest in life. Meanwhile, individuals who have a positive self-concept will be optimistic, self-confident and always be positive about everything, as well as the failures experienced.

Mastectomy will affect self-concept including one's body image. Body image is defined as a mental picture of a person's body, attitudes about physical self, appearance, and state of health, wholeness, normal functioning, and sexuality (Fobair, 2006). For some individuals, changes in appearance can cause negative body image and various psychosocial problems. Negative body image among breast cancer sufferers includes dissatisfaction with appearance, loss of femininity and perceived body integrity, unwillingness to see yourself naked, feeling less sexually attractive, self-awareness of appearance, and dissatisfaction with surgical scars (Fobair, 2006 ) Some studies emphasize that breast cancer patients can experience changes in body image, self-concept, emotions, behavior, family dynamics, and the role of patients and their families (Özbaş, 2006: Arroyo, 2011).

If the disruption of self-concept continues, it will lead to emotional weakness. Individuals will be depressed and feel anxiety continuously, emotional disappointment that gets worse, makes individuals create selfdestruction. Negative self-concept if it is continuously allowed to develop makes the body easily sick, despair and depression because of the lack of a strong inner endurance. As a result it interferes with the nervous and immune systems such as being easily agitated, anxious, scared, worried, easily runny, coughing and diseases that are actually considered light and trivial but have a huge impact on health (Berterö, 2002). For this reason, a therapy that can overcome the problem of negative self-concept is needed.

Spiritual Therapy Emotional Freedom Technique (SEFT) including relaxation techniques, is one form of mind-body therapy from complementary and alternative therapies in nursing. SEFT is a technique of combining the body's energy system (energymedicine) and spiritual therapy by using tapping methods at certain points on the body. SEFT therapy works on a principle more or less the 
Esi Afriyanti : The Effect of Spiritual Emotional Freedom Technique (SEFT) on the Self Concept

same as acupuncture and acupressure. All three try to stimulate key points along the 12 energy pathways (energy meridians) of the body. The difference between the methods of acupuncture and acupressure is that the SEFT technique uses spiritual elements, the method used is safer, easier, faster and simpler, because SEFT only uses tapping (Zainuddin, 2009; Thayib, 2010; Saputra, 2012).

Research on EFT, which is the root of SEFT has been carried out in various areas. EFT is able to reduce symptoms of Post Traumatic Stress Dysorder (PSTD) (Swingle, Pulos, \& Swingle, 2005), able to reduce eatingphobia in children (McCarty, 2008, in Zainuddin, 2009), making Traumatic Brain Injury (TBI) sufferers quieter, cure phobia in just 30 minutes (Benor et al., 2008; Craig et al., 2009; Wells et al., 2000; Baker \& Siegel, 2000 in Zainuddin, 2009). In addition EFT is very significant in overcoming fear, paranoid, obsessive, depression, and other psychological disorders (Waite \& Holder, 2003; Church, Geronilla, \& Dinter, 2006 in Zainuddin, 2009).

The application of SEFT was carried out by Anwar (2011) on patients with specific phobias. The results of his research show that SEFT therapy can reduce excessive fear. Hakam et al. (2009) conducted a SEFT intervention study to reduce pain in stage $\mathrm{IIb}$ cervical cancer patients. However, studies related to the effects of SEFT on self-concept, especially patients with mastectomy have not been found.

\section{Method}

The design of this study is a quasi experiment with the one group pretest-posttest design, namely in this design in a group of research subjects 2 measurements were taken in patients who experienced self-concept disorder due to mastectomy, namely the first measurement (pre-test), then an intervention in the form of Spiritual Emotional Freedom Technique (SEFT). The provision of SEFT therapy to the study subjects was carried out for \pm 10 minutes, with the following time allocation: \pm 3 minutes for the set-up phase and \pm 7 minutes for the tune-in phase and the tapping done simultaneously. After being sure that the research subject did it correctly according to the procedure, the research subjects were required to do therapy at least 1 time a day. Every subject had SEFT therapy, so the subject of the research must give a chechlist on the list of exercises at home. Interventions continued at home will be carried out by researchers using the telephone. After 3 days of intervention, a period of time considered sufficient based on several studies, the research team will conduct a home visit to measure the self-concept of the subject measured again (posttest). The research subject was taken in $\mathrm{M}$. Djamil Hospital Padang in the section of Surgery in February - December 2017. The population in this study were all breast cancer patients who had undergone a mastectomy and had undergone outpatient care and had interacted with family and society. The sample in this study were patients with breast cancer patients who had undergone mastectomy and met the inclusion and exclusion criteria. The sample size required in this study was 33 people with sampling taken by consecutive sampling based on the inclusion and exclusion criteria made by the researcher. The inclusion criteria in this study were willing to be a research subject, aware, not having hearing or cognitive impairment experiencing selfconcept disorder, had never done SEFT therapy. While the exclusion criteria in this study were subjects experiencing impaired consciousness due to the disease process, the study subjects dropped out of the study by refusing to continue the intervention before the intervention time was completed $(<3$ days).

The independent variable in this study was Spiritual Emotional Freedom Technique (SEFT), while the dependent variable was self-concept. Self-concept instruments that are used first are tested for validity and reliability. Respondent characteristics data (employment, education) are explained by percentage and proportion values. Bivariate analysis using Chi Square statistical test using a significance level of 0.05 and a $95 \%$ CI degree of confidence. 
Esi Afriyanti : The Effect of Spiritual Emotional Freedom Technique (SEFT) on the Self Concept

\section{Result}

Of the 33 breast cancer sufferers who mastectomy, it was found that the highest respondent age was in the range of 3442 years, namely 13 respondents $(39.4 \%)$ and the highest respondents' education was elementary school (SD) as many as 18 respondents $(54.5 \%)$. Respondents generally married as many as 33 respondents $(100 \%)$, Muslim 24 respondents $(72.7 \%)$, where they generally worked only as housewives as

Table 1 Characteristics of Respondents

\begin{tabular}{|c|c|c|c|}
\hline \multicolumn{2}{|c|}{ Characteristics of Respondents } & f & $\%$ \\
\hline \multicolumn{4}{|c|}{ Age } \\
\hline- & $25-33$ year & 6 & 18.2 \\
\hline - & $34-42$ year & 13 & 39.4 \\
\hline- & $43-51$ year & 10 & 30.3 \\
\hline- & $52-60$ year & 2 & 6.1 \\
\hline- & $61-69$ year & 2 & 6.1 \\
\hline \multicolumn{4}{|c|}{ Pendidikan } \\
\hline- & Elementary School (SD) & 18 & 54.5 \\
\hline- & Junior High School (SMP) & 8 & 24.2 \\
\hline$\overline{\text { (S }}$ & Senior High School & 6 & 18.2 \\
\hline- & College & 1 & 3.0 \\
\hline \multicolumn{4}{|c|}{ Pekerjaan } \\
\hline- & Government Employees & 1 & 3.0 \\
\hline- & Wiraswasta & 6 & 18.2 \\
\hline- & Enterpreneur & 4 & 12.1 \\
\hline- & Farming & 5 & 15.2 \\
\hline- & Housewife & 17 & 51.5 \\
\hline
\end{tabular}

Table 2 Frequency Distribution of Self-Concept of Women with Breast Cancer $(\mathrm{N}=33)$

\begin{tabular}{ccccccc}
\hline $\begin{array}{c}\text { Self Concept of Women with } \\
\text { Breast Cancer with mastectomy }\end{array}$ & \multicolumn{2}{c}{ Before therapy } & \multicolumn{2}{c}{ After therapy } & \multirow{2}{*}{ p } \\
\cline { 2 - 5 } & $\mathbf{f}$ & $\mathbf{\%}$ & $\mathbf{f}$ & $\mathbf{\%}$ & \\
\hline Positive & 4 & 12.1 & 10 & 30.3 & 0.05 \\
Negative & 29 & 87.9 & 23 & 69.7 & \\
\hline
\end{tabular}

Table 3 Frequency Dstribution and Percentage of Self-Concept Components in Women with Mastectomy

\begin{tabular}{lcc}
\hline \multicolumn{1}{c}{ Self Concept Components } & f & \% \\
\hline \multicolumn{1}{c}{ Self-image } & & 39.4 \\
\hline Positive & 13 & 60.6 \\
Negative & 20 & \\
Self Ideal & & 24.2 \\
Reality & 8 & 75.8 \\
Not Reality & 25 &
\end{tabular}


Esi Afriyanti : The Effect of Spiritual Emotional Freedom Technique (SEFT) on the Self Concept

\begin{tabular}{lcc} 
High & 12 & 36.4 \\
Low & 21 & 63.6 \\
\hline Role & 8 & \\
Satisfied & 25 & 75.2 \\
Dissatisfaction & & \\
Self Identity & 16 & 48.5 \\
Identity Clarity & 17 & 51.5 \\
Identity Unclear & & \\
\hline
\end{tabular}

many as 17 respondents $(51.5 \%)$. The results of the study regarding the characteristics of respondents in brief can be seen in table 1 .

This study shows that from 33 women with breast cancer with mastectomy who became the research respondents obtained the following data that before being given SEFT treatment there were 4 respondents $(12.1 \%)$ who had a positive self-concept, and the majority of 29 respondents $(87.9 \%)$ who have negative self-concept. But after the SEFT treatment there was an increase in selfconcept, namely respondents with positive self-concept as many as 10 people $(30.3 \%)$ and still have negative self-concept as many as 23 people $(69.7 \%)$. After being tested with chi-square statistical tests there were differences in self-concept before and after SEFT. The results of this study can be seen in table 2.

When viewed from the components of self-concept which consists of several components namely self-image, self-ideal, self-esteem, role, and self-identity before therapy can be described as follows.

Self-image from the results of the study note that there were 20 respondents $(60.6 \%)$ had a negative self-image, this can be seen in table 3. Analysis of data that shows the negative self-image of respondents supported by the expression of respondents revealed that they disliked her breasts $(69.7 \%)$, worried that her breasts were no longer beautiful (54.5\%), were unable to function as women (12.1\%), and realized that their sexual attractiveness had disappeared $(51.5 \%)$.

Self-ideal from the results of the study, as many as 22 respondents $(66.7 \%)$ had an ideal self that was not reality. Data analysis that shows the ideal of women with breast cancer that is not reality is supported by the expression of respondents who stated that $33.3 \%$ did not want to look beautiful in front of loved ones, $12.1 \%$ expressed resignation not wanting to be a full woman, $6.1 \%$ no longer hope that the relationship with their loved ones will remain harmonious and happy, and $30.3 \%$ deny the current condition because they want the shape of their breasts to return to normal as other women. This can be seen in table 3 .

Self esteem from the results of the study note that as many as 21 respondents $(63.3 \%)$ have low self-esteem, this is supported by data showing that $12.1 \%$ revealed that during breast cancer her husband always ignored him, $6.1 \%$ did not sincerely received by the family, 36.4\% lost faith and enthusiasm in living their lives, $33.3 \%$ revealed that due to breast cancer, prevented them from doing their daily activities, and $69.7 \%$ were ashamed if other people know the disease they are experiencing. The data can be seen in table 3.

Role there were 25 respondents $(75.6 \%)$ who did not have satisfaction in the roles they performed. As many as $33.3 \%$ were not able to do a good job so they had to be assisted by others, $24.2 \%$ were no longer able to care for their families properly, $54.5 \%$ were no longer able to serve their husbands, 33.3\% no longer participate in social activities in the community, and $45.5 \%$ stated that since suffering from breast cancer they are not able to serve their husbands to the maximum. The data can be seen in table 3 .

Personal identity from the results of the study note that as many as 17 respondents 
Esi Afriyanti : The Effect of Spiritual Emotional Freedom Technique (SEFT) on the Self Concept

(45.5\%) have no clarity in the identity of this can be seen in table 3 . Analysis of data that shows identity uncertainty supported by $57.6 \%$ said breast cancer made them not become women in full, 9.1\% despair could not make her husband happy, $12.1 \%$ could not be a good mother of her children, $42.4 \%$ was prevented from hanging out with people around her, and $42.4 \%$ expressing the inferior shape of her breasts is not as beautiful as before.

\section{Discussion}

Based on Table 2, it is known that the selfconcept of women with breast cancer after mastectomy was carried out, the majority had negative self-concept, namely 29 respondents $(87.9 \%)$. According to Puckett (2007) when a woman is diagnosed with breast cancer, not only has an impact on her physical but also on her emotional and mental state, which can then affect her relationship with others. They begin to be alone, and the response to rejection of the truth of the diagnosis continues to occur (Elvira, 2008). They judge negatively their physical appearance and feel dissatisfied with their physical condition (Chris, 2005). Patients with breast cancer will display a negative impression such as shame and low self-esteem towards others. The feeling of shame and inferiority felt by breast cancer sufferers is related to the physical condition that is felt to be imperfect anymore and not in accordance with what he expected (Chris, 2005).

In the self-image can be seen that as many as 23 respondents $(69.7 \%)$ said they did not like performance breasts anymore after suffering from breast cancer, 18 respondents $(54.5 \%)$ worried about the shape of her breasts is not beautiful anymore after suffering from breast cancer, 4 respondents (12.1\% ) feeling unable to function as a woman because of having imperfect breasts and 17 respondents $(51.5 \%)$ revealed that her sexual attraction was gone after suffering from breast cancer. According to Hawari (2003) breast is one of the characteristics of secondary sex which has an important meaning for women, not only as one of the identities that she is a woman, but has a separate value in terms of biological, psychological, psychosexual and psychosocial. This is also corroborated by Taylor (1995), that breast loss will change the physical appearance of the patient and can affect the way he views the body image. Women feel inferior, neglected, feel imperfect as a woman. Plus other treatment effects, which can make him experience nausea, vomiting, hair loss, and menopausal symptoms. A woman who has not experienced menopause, because of the effects of treatment she has experienced menopause earlier. He felt this could threaten his marriage life.

On ideal self was also found that as many as 4 respondents $(12.1 \%)$ showed despair and expressed that they could not be women as a whole, 3 respondents $(6.1 \%)$ said they did not expect the relationship with loved ones to remain harmonious and happy after suffering from cancer breast. As many as 2 respondents $(6.1 \%)$ said they could not maximize themselves in carrying out their functions as mothers in the family and as many as 10 respondents $(30.3 \%)$ denied the current condition, wanting their breasts to return to normal as other mothers in general. Women become less perfect because as a mother can not breastfeed her child (Herawati, 2005).

Based on the study also found that selfesteem as many as 29 respondents $(87.9 \%)$ stated that even though they had breast cancer, their husbands never ignored them and as many as 31 respondents (93.3\%) stated that their families would continue to accept sincerely even though their condition was like that. This shows that the support and acceptance of various parties is very meaningful for patients with breast cancer. The results of this study are supported by research conducted by Anggraini (2006) that the need for social support for women with high breast cancer. This is also consistent with Sharp's (2000) opinion in Abraham and Shanley (1997) that women diagnosed with breast cancer need high levels of social support needs. Social support according to Keliat (1998) including spouses, parents, children, relatives, friends, health team, superiors, counselors and so on. The above opinion is also corroborated by the opinion of Koopman et al. (1998) that breast cancer 
Esi Afriyanti : The Effect of Spiritual Emotional Freedom Technique (SEFT) on the Self Concept

sufferers experience enormous life stress so they desperately need social support. From the results of the study also revealed that only 21 respondents $(63.7 \%)$ had confidence and enthusiasm in carrying out life while as many as 11 respondents (36.3\%) lost faith and enthusiasm in living a life. According to cancer patients, when the verdict came, they were discouraged because they thought of expensive costs and negative things due to side effects of surgery and chemotherapy. Even imagined death before the eyes or prolonged pain during treatment (Elvira, 2008).

From role respondent the results of the study found that 11 respondents $(33.3 \%)$ revealed that since suffering from breast cancer, they could not do the job well, and as many as 8 respondents $(24.2 \%)$ said they were not able to care for the family properly. And as many as 11 respondents (33.3\%) since suffering from breast cancer cannot do social activities in the community. The results also found that as many as 18 respondents $(54.5 \%)$ claimed to be a wife, they were not able to serve their husbands to the maximum. Psychological factors experienced by cancer patients often affect their views on organs and sexual function, namely role disorder, thus affecting their inadequate feeling in sexual function.

From self identity respondent found that as many as 19 respondents $(57.6 \%)$ stated that breast cancer prevented them from associating with the people around him and strengthened by the answer from the respondent's statement that 19 respondents $(57.6 \%)$ claimed to be women they were inferior because the shape of her breasts is not as beautiful as before. In line with the research conducted by Chris (2005) on selfconcept in women with post-operative breast cancer, it was found that feelings of shame and inferiority that are felt by the subject relate to the physical condition that is felt incomplete again and not in accordance with what he expected. Patients with breast cancer post operative action will feel they do not have the ability to do both activities and to establish socialization relationships with others. Physical conditions that are no longer intact cause cancer sufferers to feel that they have weaknesses that have an impact on the feeling of not having the ability to do something.

Based on chi-square statistical test there are differences in self-concept before and after SEFT performed with a value of $p$ $<0.05$. The results of Richman's research (2010) also explain that emotional stress that continues continuously can ultimately increase the level of individual anxiety and can even cause depression. Emotional pressure that comes from the experience of a chronic disease will generate various feelings and stress reactions, including frustration, anxiety, anger, denial, shame, grief and uncertainty. Those who experience chronic diseases coupled with mastectomy therapy, sometimes become very sensitive and vulnerable. His whole life changed, at least temporarily. They are overshadowed by memories of the past while facing uncertain current and future realities. The things about death, dependence, powerlessness and lower self-esteem will surface.

SEFT therapy includes relaxation techniques, is one form of mind-body therapy from complementary and alternative therapies in nursing. This technique combines the body's energy system (energy medicine) and spiritual therapy which is used as one of the therapeutic techniques to overcome emotional and physical problems, namely by tapping the nerve points (body meridians). Spiritual in SEFT is a prayer that is affirmed by the client when it will begin until the therapy session ends, namely in the set-up, tune-in and tapping phases. In the set-up phase, patients are asked to pray to God with a sense of khusyu', sincere and surrender that whatever problems and pain they are experiencing right now, we are sincere in accepting and we surrender their healing to God Almighty. In the tune-in phase, it is done by feeling the pain experienced, then directing the mind to the place of pain, accompanied by heart and mouth saying a prayer: "O God I am sincere, I am resigned ..." or "O God I sincerely accept my pain this, I surrender to you my healing ". Along with this tune-in we do the third phase, namely tapping. In this process (tune-in accompanied by tapping), we neutralize negative emotions or physical 
Esi Afriyanti : The Effect of Spiritual Emotional Freedom Technique (SEFT) on the Self Concept

pain. Patients are also asked to say a prayer with certain sentences when each meridian points are tapped lightly during tapping (Zainuddin, 2009).

Sumiati (2010) mentions in her book that prayer is part of worship, it is an acknowledgment that a person depends on the only God who creates man and the universe. With this recognition, a sense of security arises in the human soul, that there is a very close supporter of his life, which will not make him sad. The value of worship is very important in reducing emotional stress so that it affects the process of hypertension and its prognosis. By increasing worship motivation and worship, it will strengthen one's mental and psychological well-being and get calm. With the remembrance of Allah, the day will be calm and serene, as the word of God in the Qur'an Al-Rad (13:28). God said: “Those who believe and their hearts are at peace with the remembrance of Allah. Remember, only by remembering Allah is the heart serene" (Sumiati, 2010).

The influence of spiritual aspects on healing, disease management, anxiety and acceptance of death has been the concern of nurses. Nursing care includes human spiritual recognition and support. The spiritual character in nursing shows the recognition that unseen and untouchable natural factors influence thoughts and behavior. This introduction includes religion and supernatural beliefs. When people feel external strength and influence from physical existence and time, they are said to have experienced the metaphysical aspects of spiritual character. Supporting and allowing patients to talk about their beliefs will bring them closer to the source of their spiritual drive. This helps provide strength and healing (Hudak, 1997).

Some of the descriptions above explain that the benefits of a spiritual approach for patients are to provide calm, hope and strengthen mentally during illness or while undergoing treatment in a hospital. Patients become more relaxed in their daily lives. Smeltzer (2004) states that relaxation produces responses that can combat stress responses. That's where the power of SEFT therapy uses spiritual elements.

\section{Conclusion}

Before SEFT therapy, the majority of respondents $(87.9 \%)$ had negative selfconcept and only $12.1 \%$ had a positive self-concept in themselves, after the SEFT treatment there was an increase in selfconcept, namely respondents with positive self-concept as many as 10 people $(30.3 \%)$ and still have negative self-concept as many as 23 people $(69.7 \%)$.

There are differences in self-concept in women who suffer from breast cancer with mastectomy after being treated with SEFT therapy with a value of $p=0.05$. It is advisable for nurses to be able to train this SEFT ability as a complementary therapy and can teach patients and families so that they can do it independently. For nursing managers can consider making the results of this study as a basis for preparing nursing care plans or operational standard procedures for patient care.

\section{References}

Abraham and Shanley. (1997). Psikologi sosial untuk perawat. Jakarta: EGC.

Anggraini, Y. T. (2006). Kebutuhan Dukungan Sosial Wanita Kanker Payudara di RSU Dr. Pirngadi Medan. Skripsi. Tidak Dipublikasikan.

Anwar, Z. (2011). Model Terapi SEFT (Spiritual Emotional Freedom Technique) Untuk Mengatasi Gangguan Fobia Spesifik. Juli, 2011. Universitas Muhammadiyah Malang, Direktorat Penelitian Dan Pengabdian Kepada Masyarakat.

http://www.umm.ac.id.

Arroyo, J.M., Lopez, M.L.D. (2011). Psychological Problems Derived from Mastectomy: A Qualitative Study. International Journal of Surgical Oncology Volume 2011, Article ID 132461, 8 pages 
Esi Afriyanti : The Effect of Spiritual Emotional Freedom Technique (SEFT) on the Self Concept

http://dx.doi.org/10.1155/2011/132461.

Balitbang Basic Health Research Ministry of Health, 2013. Basic health research. http:// www.depkes.go.id/resources/download/ general/Hasil\%20Riskesdas\%202013.pdf.

Berterö Carina M. (2002). Affected selfrespect and self-value: the impact of breast cancer treatment on self-esteem and QoL. Volume 11, (4): 356-364.

Cebeci F, Yangın H.B., Tekeli A. (2012). Life experiences of women with breast cancer in south western Turkey: A qualitative study. European Journal of Oncology Nursing, 16(4), September 2012, Pages 406-412.

Chris, N.S. (2008). Gambaran konsep diri wanita penderita kanker payudara pasca tindakan operatif. Jurnal keperawatan. Dikutip dari http://library.gunadarma.ac.id/ index.php? appid $=$ penulisan\&sub $=$ detail $\& n p$ $\mathrm{m}=10501208 \&$ jenis $=\mathrm{d} 3$ filkom.

Elvira, S. (2008). ketika kanker vonis datang. Dikutip dari http://mitrafm.com/ blog/2008//11/18/ketika-vonis-kanker-itudatang.

Fobair, P., Stewart, S. L., Chang, S., D’Onofrio, C., Banks, P. J., \& Bloom, J. R. (2006). Body image and sexual problems in young women with breast cancer. PsychoOncology, 15(7), 579-594. https://doi. org/10.1002/pon.991.

Gnant M., Thomssen C., Harbeck N. (2015). St. Gallen/Vienna 2015: A Brief Summary of the Consensus Discussion. Breast Care 10:124-130. DOI: 10.1159/000430488.

Hakam, M., Yetti, K., \& Hariyati, R. S. T. (2009). Intervensi Spiritual Emotional Freedom Technique (SEFT) untuk mengurangi rasa nyeri pasien kanker. Makara Kesehatan,95-99.

Hawari, D. (2006). Manajemen stres, cemas dan depresi. (Ed. 2). Jakarta: Balai Penerbit FKUI.

Herawati (2005). Gambaran body image pada wanita penderita kanker payudara yang sudah menjalani operasi. https://library.gunadarma. ac.id/.

Hudak, C. (1997). Keperawatan Kritis : Pendekatan Holistik. Jakarta : EGC.

Keliat, B. A (1998). Gangguan Konsep Koping, citra tubuh dan seksual pada klien kanker. Jakarta: EGC.

Koçan S, Gürsoy A. (2016). Body Image of Women with Breast Cancer After Mastectomy: A Qualitative Research. $J$ Breast Health, 12: 145-50 DOI: 10.5152/ tjbh.2016.2913.

Koopman et al. (1998). Sosial Support, Life Stress, Pain and Emotional Adjusment

to Advanced Breast Cancer.

Dikutip dari

http://www.ncbi.nlm.nih.gov/entre\&/qvery. fcgi?cmd=Retrieve $\& \mathrm{db}=$ pubmed.

Özbaş A (2006). problems and solutions of breast cancer families. The Jurnal of Breast Health, 2:115-7.

Saputra,A. (2012). Buku Terapi Emotional Freedom Technique. Yogyakarta: NQ Publishing.

Smeltzer, S. C. (2004). Buku Ajar Keperawatan Medikal Bedah Brunner \& Suddart. ed. 8. Vol. 2. Jakarta : EGC.

Stuart \& Sundeen, (1991). Buku Saku Keperawatan Jiwa. Edisi 1. Jakarta:EGC.

Sumiati. (2010). Penanganan Stress Pada Penyakit Jantung Koroner. Jakarta : Trans Info Media.

Sunaryo. (2004). Psikologi untuk keperawatan. Jakarta: Penerbit Buku Kedokteran EGC.

Swingle, P., Pulos, L., \& Swingle, M. K. (2005). Neurophysiological indicators of EFT treatment of post-traumatic stress. Subtle Energies and Energy Medicine, 15(1),75-86. 
Esi Afriyanti : The Effect of Spiritual Emotional Freedom Technique (SEFT) on the Self Concept

Taylor (1995). Factors influencing cosmetic results after conservation therapy for breast cancer. International Jurnal Radiation Oncology, 31(4), 753-764.

Thayib, S. (2010). Preview Spiritual
Emotional Freedom Technique. Surabaya : LoGOS Institute.

Zainuddin, A.F. (2009). Spiritual Emotional Freedom Technique. Jakarta:Afzan Publishing. 